\title{
Effect of llama (Lama glama) manure and Trichoderma strain T1R3 on arsenic uptake by Swiss chard and broad bean crops. A strategy to minimize health risks
}

\author{
Luciano Matias Yañez ( $\square$ lumaya12@hotmail.com ) \\ UNJU: Universidad Nacional de Jujuy https://orcid.org/0000-0002-1488-3129 \\ Jimena Agustina Alfaro \\ UNJU: Universidad Nacional de Jujuy \\ Natalia Maria Elisa Ávila Carreras \\ UNJU: Universidad Nacional de Jujuy \\ Graciela Bovi Mitre \\ UNJU: Universidad Nacional de Jujuy
}

\section{Research Article}

Keywords: Arsenic, Vegetable, Organic amendment, Mitigation, Human health risk, Jujuy-Argentina

Posted Date: February 11th, 2022

DOI: https://doi.org/10.21203/rs.3.rs-1258357/v1

License: (c) (1) This work is licensed under a Creative Commons Attribution 4.0 International License.

Read Full License 


\section{Abstract}

The town of Pastos Chicos (Jujuy-Argentina), presents arsenic (As) concentrations in soil (49 mgAs kg ${ }^{-1}$ ) and water $\left(1.44 \mathrm{mgAs}^{-1}\right)$ significantly above the maximum allowable limits set by National Laws $\mathrm{N}^{\circ}$ 24,585 and $\mathrm{N}^{\circ} 24,051$. This study aimed to evaluate the effect of llama manure (Lama glama) and Trichoderma strain T1R3 on As uptake and toxicity in Swiss chard (Beta vulgaris var. cicla) and broad bean (Vicia faba L.) crops, while assessing potential human health risks. Results indicated that Trichoderma strain T1R3 inoculation stimulated broad bean plant growth by reducing As stress. Swiss chard crops treated with 5\% manure and a manure/ Trichoderma T1R3 combination reduced As absorption from 32.46 to $64.02 \%$ in roots, and from 35.2 to $44.5 \%$ in leaves. Broad bean crops inoculated with Trichoderma T1R3 showed a significant mitigation of toxicant accumulation in the leaves (67.42\%). Also, the manure/ Trichoderma T1R3 combination reduced As accumulation (57.46\%) in broad bean roots. The efficacy of llama manure and of the llama manure/ Trichoderma T1R3 combination in reducing health hazards that derive from As intake by consuming chard leaves was also reflected in Hazard Quotient $<1$ values. Although Cancer Risk values decreased considerably, these showed there was a considerable carcinogenic risk for humans consuming chard leaves. These observations reveal that adding llama manure and Trichoderma T1R3 might mitigate As uptake by crops, thus reducing human health risks. This study advanced our understanding the complex llama manure/ Trichoderma strain interactions in As-contaminated soils, which are imperative for developing the effective mitigations strategies.

\section{Highlights}

- Trichoderma strain stimulated broad bean plant growth by reducing As stress.

- Llama manure and a Trichoderma reduced As absorption in chard roots and leaves.

- Addition of llama manure increased soil fertility and available phosphorus content.

- Llama manure and Trichoderma reduced As accumulation (57.46\%) in bean roots.

- The llama manure and Trichoderma combination reduced As health hazard.

\section{Introduction}

Arsenic (As) is a hazardous element, which represents a significant risk to human health when introduced into the food chain, skin exposure, and inhalation (Farooq et al. 2016). Prolonged exposure to As by consuming water or food that contains certain As levels causes serious toxic effects, including skin lesions (pigmentation and keratosis) and lung and bladder cancer (Mandal et al. 2019). Therefore, immobilizing As in contaminated soils may constitute an effective strategy to reduce its accumulation in plants and food (Arco-Lázaro et al. 2016). Actions to mitigate As toxicity and mobility in plants involve the use of organic amendments, and the inoculation of soil with beneficial microorganisms, such as bacteria and ectomycorrhizal fungi (Luo et al. 2016; Nawab et al. 2018). In particular, the genus Trichoderma tolerates heavy metals, and using it to immobilize and remove As constitutes an eco-friendly 
and cost-effective bioremediation technique to clean up soils contaminated with heavy metals (Govarthanan et al. 2018; Govarthanan et al. 2019a). Trichoderma species are of particular interest, as they can survive under a range of environmental conditions and stimulate plant growth and development, by improving water and nutrient absorption from the soil (Tripathi et al. 2017). Several Trichoderma strains are well known for their ability to ameliorate abiotic stress in plants by inducing physiological protection, enhancing antioxidant capacity, and endowing plants with resistance to high temperature, high salinity and drought conditions (Khoshmanzar et al. 2019; Poveda 2021). An important function is bioremediation, where Trichoderma strains can remediate As-contaminated environments by triggering the transformation of As species through reduction, oxidation, methylation, demethylation, and cellular sequestration ( $\mathrm{Li}$ et al. 2021). Also, these fungi induce a higher root biomass production, and increase tolerance to As-mediated stress, reducing As accumulation in plants (Caporale et al. 2014). For example, Tripathi et al. (2015) reported that inoculation with Trichoderma reesei reduced As toxicity in chickpea plants grown in soils contaminated with $100 \mathrm{mg} \mathrm{kg}^{-1}$ As, mitigating As concentration in edible part plants. Recently, it has been shown that inoculation of soil with beneficial microorganisms, such as Trichoderma asperellum SM-12F1, caused As methylation in the soil (Su et al. 2017). This loss of As contents may be due to the volatilization of methylated As, for example, as methylarsonic acid (MMA), and dimethylarsinic acid (DMA), which reduces As phytotoxicity and improves plant growth (Zhang et al. 2018).

Organic amendments have been used by many researchers to immobilize toxic metals in contaminated soils (Nawab et al. 2016; Govarthanan et al. 2019b). For example, Joardar and Kawai (2014) showed that application of pig manure (1,2, and $3 \%)$ with high phosphorus concentrations reduces As concentration $(39,52$ and $66 \%$, respectively) in edible parts of Japanese mustard spinach irrigated with Ascontaminated water. As phosphorus and As are chemical analogs that are taken up by plants through the same transporters, a high phosphorus content in plant cells can lead to increased competition with As (V) through different biochemical processes (Niazi et al. 2017). Also, Urunmatsoma et al. (2010) demonstrated that the addition of cow dung in chromated copper arsenate contaminated soil decreased $\mathrm{Cr}, \mathrm{Cu}$ and As mobility and uptake in maize (Zea mays). Gadepalle et al. (2008) and Liu et al. (2009) reported that the addition of compost to soils resulted in As complexation/adsorption with the humic substances, decreasing its mobility and phyto-availability in the soils, which made revegetation possible in sites contaminated with As.

The Puna region (Jujuy-Argentina) is a high plateau which rises over 3500 meters above sea level. The soil in this area is arid, and As contamination has a geogenic source. The climate is characterized by a wide temperature range, intense solar radiation, constant winds, low average temperatures and scarce rainfall, which occurs mainly in the summer months, while usually reaching zero levels in winter (PIP 2016). The region is considered a nucleus of biological diversity, whose preservation and protection is in the hands of small producers, who keep traditional small-scale agricultural practices, based on only their knowledge and inputs (PIP 2016). Local studies are mainly focused on Swiss chard and broad beans, as they are viewed as traditional regional crops that contribute to a balanced diet rich in nutrients, such as 
proteins, vitamins, amino acids, and minerals, among others. These crops are produced in areas with high As contents in water and soil, exceeding the allowable limits established by the National Law $N^{\circ} 24,051$ (0.10 mgAs L ${ }^{-1}$ in irrigation water), and by National Law $\mathrm{N}^{0} 24,585$ (20 mgAs kg${ }^{-1}$ in agricultural soil) (Yañez et al. 2018 and 2019). Vegetables are generally highly sensitive to metal stress, and become a source of As poisoning for humans who grow and consume them. This has caused interest amongst scientists, who are exploring some sustainable and eco-friendly option for remediation and restoration of As-contaminated soils (Mehmood et al. 2017). Therefore, adding organic amendments and beneficial fungi to soil could reduce As accumulation in crops grown in areas polluted with this toxicant, diminishing its translocation to edible plant parts, and thus making agriculture safer and more sustainable.

This study aimed to evaluate the effect of llama manure (Lama glama) and Trichoderma strain T1R3 on As uptake and toxicity in Swiss chard (Beta vulgaris var. cicla) and broad bean (Vicia faba L.) crops, as well as assessing potential risks to health of humans consuming these vegetables.

\section{Materials And Methods}

\subsection{Arsenic contaminated soil, llama manure and irrigation water sampling}

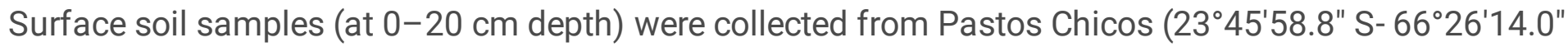
$W$ ), in the Susques-Puna Region (Jujuy-Argentina), whereas llama manure samples were collected from a pen near Pastos Chicos $\left(23^{\circ} 38^{\prime} 39.1^{\prime \prime} \mathrm{S}-66^{\circ} 25^{\prime} 07.6^{\prime \prime} \mathrm{W}\right)$. The soil and manure samples were air-dried, sieved $(2 \mathrm{~mm})$ and then homogenized prior to determination of $\mathrm{pH}$ and organic matter by potentiometry and wet digestion employing the Walkley-Black method, respectively (Nelson and Sommers 1982). Electrical conductivity was measured using the saturation extract method. Other determinations were total nitrogen, according to Bremner and Mulvaney (1982); bioavailable phosphorus content, by means of Bray and Kurtz's method (1945); and sodium and potassium complexes by flame photometry (Eaton et al. 2005). The soil and llama manure were processed for total As quantification using acid digestion according to USEPA method 3050 B (1996). Pulverized samples $(0.5 \mathrm{~g})$ were transferred to Teflon beakers, where $10 \mathrm{~mL}$ of $50 \% \mathrm{HNO}_{3}$ was added. The solutions were heated on a hot plate at $95^{\circ} \mathrm{C} \pm 5$ with a watch glass for $2 \mathrm{~h}$, until they evaporated (without boiling) to about $5 \mathrm{~mL}$. Subsequently, $3 \mathrm{~mL}$ of hydrogen peroxide $\left(30 \% \mathrm{H}_{2} \mathrm{O}_{2}\right)$ was added, and the solutions were again heated until the sample suffered no further changes in its appearance. Finally, $10 \mathrm{~mL}$ of concentrated $\mathrm{HCl}$ was added to the solutions, followed by hot plate heating $\left(95^{\circ} \mathrm{C} \pm 5\right)$ for $15 \mathrm{~min}$. After digestion, total As concentration was determined with a hydride generation-atomic absorption spectrometer (HG-AAS), methodology described below. Irrigation water was collected from Río Pastos Chicos (Susques) $\left(23^{\circ} 42031.300 \mathrm{~S}-66^{\circ} 26042.300 \mathrm{~W}\right)$. The following parameters were analyzed, among others: temperature, $\mathrm{pH}$ (potentiometry), electrical conductivity (conductivity meter), magnesium and calcium by complexometric volumetric titration as quantified with EDTA (ethylenediaminetetraacetic acid), sodium and potassium complexes as measured 
by flame photometry, and carbonates, bicarbonates, chlorides, and sulfates as determined by neutralization titration. Total As in water was quantified using a HG-AAS (Yañez et al. 2018).

Soil, water, and llama manure were collected in a single sampling to avoid variations in physical-chemical properties and As content.

\subsection{Microorganism and culture conditions}

The fungus used was As tolerant Trichoderma strain T1R3 previously selected by Yañez et al. (2017). To obtain an appropriate inoculum (spore suspensions), strain T1R3 was pre-cultivated on potato dextrose agar (PDA) medium, and incubated for 7 days at $28^{\circ} \mathrm{C}$. Subsequently, $10 \mathrm{~mL}$ of sterile $0.85 \% \mathrm{NaCl}$ was added to release the chlamydospores from the surface of the medium. The filtered suspension was vigorously stirred and subsequently centrifuged at $9000 \mathrm{xg}$, for $10 \mathrm{~min}$. The supernatant was discarded, and the precipitated chlamydospores were re-suspended in sterile $0.85 \% \mathrm{NaCl}\left(10^{7}\right.$ log units $\left./ \mathrm{mL} \mathrm{CFU}\right)$.

\subsection{Aqueous extract of llama manure}

An aqueous manure extract was prepared by finely disintegrating the manure in a mortar, and sieving it with a $2 \mathrm{~mm}$ pore size mesh to remove stones, plastic, paper, among other elements. Afterwards, a suspension was made in $5 \%$ distilled water, and stirred for $12 \mathrm{~h}$ at $150 \mathrm{rpm}$. This aqueous suspension was then filtered to remove the non-solubilized material, and the resulting extract was kept cold until its use.

\subsection{Arsenic uptake mitigation experiments}

The broad bean seeds used in the trial belonged to the Agua Dulce variety and were provided by the "Pro Huerta" program of Ministerio de Desarrollo Social de la Nación Argentina, whereas the Swiss chard (Beta vulgaris var. cicla) seeds were supplied by the company Emeral Seeds-USA.

The chard seeds were germinated in multipot trays and transferred to black polyethylene bags, each containing $1 \mathrm{~kg}$ of soil. Each broad bean seed was kept in a bag too, and sown directly into $3 \mathrm{~kg}$ of soil. The chard and broad bean tests lasted 60 and 180 days, respectively. The crops were grown in soil typical of Pastos Chicos and irrigation water came from the local river (Yañez et al. 2018). Constant volumes of irrigation waters were added to each pot of the experiment, in order to maintain the soil moisture at

$70 \%$ of the field capacity, avoiding any phenomenon of leaching. Different pot experiments were carried out in a greenhouse at ambient temperature, with a natural light and darkness regime. The seeds were surface sterilized and dipped in a Trichoderma T1R3 chlamydospores suspension inoculum, at a CFU of $10^{7} \log$ units/mL. One month after cultivating chards, and two months after cultivating broad beans, these were again inoculated with $1 \mathrm{~mL}$ of the spore suspension, and with $10 \mathrm{~mL}$ of the aqueous llama manure extract. In this study, As uptake mitigation experiments had a completely randomized design, with a total of 60 pots, including the amended and control soils, was prepared in triplicate.

The treatments were as follows: 
1) Chard seedlings and broad bean seeds in soil with As, irrigated with As-contaminated water (control).

2) Chard seedlings and broad bean seeds in soil with As, irrigated with As-contaminated water and applied with $5 \%(\mathrm{w} / \mathrm{w})$ llama manure.

3) Chard seedlings and broad bean seeds in soil with As, irrigated with As-contaminated water and applied with a Trichoderma T1R3 spore suspension.

4) Chard seedlings and broad bean seeds in soil with As, irrigated with As-contaminated water and application of $5 \%$ Ilama manure (w/w) and a Trichoderma T1R3 spore suspension.

Salinity reduces plant growth, development, yield and seed quality when the concentration the salts reaches $4 \mathrm{dS} \mathrm{m}^{-1}$ (Acosta-Motos et al. 2017). Thus, the $5 \%$ llama manure was chosen according to electrical conductivity of $3.42 \mathrm{dS} \mathrm{m}^{-1}$ in the manure-soil combination.

For dry weight and As content analysis, roots and aerial parts different plant parts were oven dried at $70^{\circ} \mathrm{C}$ for $72 \mathrm{~h}$. Samples had been dried following the As quantification methodology (as described below), but the dry weight values were turned into wet weight, so as to reveal the potential health risks brought about by consuming produce from these crops. The As concentration in wet weight was determined considering a humidity of $90.6 \%$, according to the following equation: wet weight concentration = dry weight concentration $\times(1-\%$ humidity) (Costa et al. 2003).

Arsenic mobility in the chard and broad bean crops was evaluated by estimating translocation factors (TF) according to following equation:

$$
\mathrm{TF}=\frac{\text { AsT aerial }}{\text { AsT root }}
$$

Where, AsT aerial and AsT root represent the total As concentration in the aerial and root plant (Sharma et al. 2020).

\subsection{Non-carcinogenic health risks}

The health risk represented by the intake of As through consumption of Swiss chard was assessed in terms of the hazard quotient $(\mathrm{HQ})$, which was calculated with the following Eq. (the corresponding parameters are explained in Table 1):

$$
\mathrm{HQ}=\frac{\mathrm{EF} \times \mathrm{ED} \times \mathrm{FIR} \times \mathrm{C}}{\mathrm{RfD} \times \mathrm{BW} \times \mathrm{AT}} \times 10^{-3}
$$

\subsection{Cancer risk assessment}

The Cancer Risk (CR) which derives from consuming Swiss chard was determined using the following equation, as described by Shahid et al. (2017) (its parameters are explained in Table 1). 


$$
\mathrm{CR}=\frac{\mathrm{C} \times \mathrm{EF} \times \mathrm{ED} \times \mathrm{FIR} \times \mathrm{CSF}}{\mathrm{BW} \times \mathrm{AT}} \times 10^{-3}
$$

A CR lower than $10^{-6}$ is considered to be negligible, one between $10^{-6}$ and $10^{-4}$ is generally considered acceptable, whereas a CR above $10^{-4}$ is deemed unacceptable, with a high potential for causing cancer (Muñoz et al. 2017).

\subsection{Total arsenic determination}

For the analysis of total As, $1 \mathrm{~g}$ dried sample of plant was digested in

a mixture of the mineralizing agent, $20 \% \mathrm{w} / \mathrm{v}$ magnesium nitrate $\left[\mathrm{Mg}\left(\mathrm{NO}_{3}\right)_{2}\right]$ and $2 \% \mathrm{w} / \mathrm{v}$ magnesium oxide (MgO). Then, $5 \mathrm{~mL}$ of $50 \% \mathrm{v} / \mathrm{v}$ nitric acid $\left(\mathrm{HNO}_{3}\right)$ was added to promote organic matter oxidation, and the sample was heated on a hot

plate at $90^{\circ} \mathrm{C}$. Finally, the preparation was muffled at $550^{\circ} \mathrm{C}$ for $24 \mathrm{~h}$ until white ash was formed. This was resuspended in $10 \% \mathrm{v} / \mathrm{v}$ hydrochloric acid $(\mathrm{HCl})$ to measure total As. The suspension was subjected to a prereduction step with a solution of potassium iodide/ascorbic acid. Arsine $\left(\mathrm{AsH}_{3}\right)$ was then formed by reaction with a solution of sodium borohydride $\left(\mathrm{BH}_{4} \mathrm{Na}\right)$ in an alkaline medium, together with a solution of $\mathrm{HCl}$ as the source of hydrogen ions using a HG-AAS (PerkinElmer AAnalyst 100, interfaced with the FIAS 400 hydride generator). The detection limit of the method was $0.1 \mu \mathrm{gAs} \mathrm{L}^{-1}$ and quantification limit

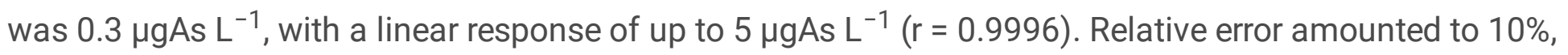
and equipment sensitivity was checked with external certified standards $\left(0.1 \mu \mathrm{gAs} \mathrm{L}^{-1}\right.$, Certipur-Merck).

\subsection{Statistical analysis}

The results are expressed as mean values with standard deviations (SDs) as a measure of dispersion (means \pm SD). The differences between individual means were compared by one-way analysis of variance (ANOVA). When significant differences were found,

Duncan's post-test was used to separate the effects among treatments. Tests were considered significantly different at $p<0.05$. These statistical analyses were performed using professional versions of Infostat software.

\section{Results And Discussion}

\subsection{Soil, llama manure and irrigation water characterization}

The physicochemical properties of the soil, llama manure, and irrigation water used in this study are presented in Table 2. The soil from Pastos Chicos presented a sandy-loan texture. As reported by Mehmood et al. (2017), a higher sand amount in the soil contributes to low As retention, which represents a greater amount of As available for the crops. Considering its electrical conductivity value $\left(1.98 \mathrm{dS} \mathrm{m}^{-1}\right)$, the soil had the characteristics of an alkaline and slightly saline type, according to Richards' criteria 
(1982). The soil presented a moderately alkaline $\mathrm{pH}$ (8.3), 5.12\% organic matter content, and a high proportion of phosphorus $\left(72.8 \mathrm{mg} \mathrm{kg}^{-1}\right)$. It also had a total As concentration of $49 \mathrm{mg} \mathrm{kg}^{-1}$, exceeding the maximum As concentration level of $20 \mathrm{mg} \mathrm{kg}^{-1}$ recommended by National Law $\mathrm{N}^{\circ} 24,585$ for agricultural soils.

The llama manure presented a slightly alkaline $\mathrm{pH}$ (7.6), and a content of organic matter (23\%) which represents a good quality organic fertilizer (Chan et al. 2016). According to Richards (1982), the electrical conductivity $\left(12.76 \mathrm{dS} \mathrm{m}^{-1}\right)$ of the saturation extract indicated a manure with high salinity. In addition, the manure revealed high contents of nitrogen (1.6\%), phosphorus $\left(418 \mathrm{mg} \mathrm{kg}^{-1}\right)$, and potassium $(23.20$ $\mathrm{cmol}_{\mathrm{C}} \mathrm{kg}^{-1}$ ), important nutrients for plant growth and development (Shrivastav et al. 2020). The chemical analysis of the llama manure showed a total As concentration of $13.3 \mathrm{mg} \mathrm{kg}^{-1}$, this reflects that water and vegetation are a source of As transfer in the food chain.

The water had a moderately alkaline $\mathrm{pH}$ (8.25), and an electrical conductivity of $2.58 \mathrm{dS} / \mathrm{m}$, which indicates very high salinity according to Richards (1954). A sodium absorption ratio (SAR) of 9.92 was found, which represents a high risk of soil salinization (Yañez et al., 2018). In addition, water analysis showed a total As content of $1.44 \mathrm{mg} \mathrm{L}^{-1}$, which was 14 -fold higher than the maximum limit allowed for irrigation water (National Law $\mathrm{N}^{\circ} 24,051$ ).

3.2 Growth of Swiss chard and broad bean crops exposed to arsenic, Ilama manure and Trichoderma T1R3

Dry biomass is a critical parameter for assessing As effects on crop growth (Niazi et al. 2017). The results showed that in the chard crops treated with llama manure alone, the total dry biomass of plants was significantly lower than the control (Fig. 1). In the T1R3 strain treatment and in those with the llama manure/ Trichoderma T1R3 combination no produced significantly differences among them and the control (Fig. 1). The As content in llama manure $\left(13 \mathrm{mg} \mathrm{kg}^{-1}\right)$, the soil $\left(49 \mathrm{mg} \mathrm{kg}^{-1}\right)$, and irrigation water (1.44 $\left.\mathrm{mg} \mathrm{L}^{-1}\right)$ negatively influenced plant growth and led to a lower biomass production. It is well known that As has negative effects on plant metabolic functions, reducing growth, and changing nutrient balance and assimilation (Mirza et al. 2016). Besides, it can interfere with photosynthetic activity, metabolic processes, and water absorption (Gusman et al. 2013). Additionally, it causes oxidative stress and lipid peroxidation due to the overproduction of reactive oxygen species (ROS), such as hydrogen peroxide, superoxide, and hydroxyl radicals (Tripathi et al. 2017). For example, Tripathi et al. (2013) showed that As stress negatively affected chickpea (Cicer arietinum L.) germination (25.9\%), and stem length (15\%) and diameter (30\%) in comparison to the control treatment. Also, they registered a significant decrease in root growth, which also affected lateral roots (58\%), and in root dry weight (66\%) and length (49\%). In addition, the high calcium content in the Pastos Chicos soil may reduce phosphate availability to plants due to the possible formation of Ca-phosphate precipitates (Mehmood et al. 2017). According to the soil texture (sandy loam), phosphorus contents added through the llama manure amendments could have displaced As ions adsorb onto sand particles, thus increasing As uptake and 
reducing plant growth (Anawar et al. 2018). Similarly, Klaber and Barker (2014) demonstrated that growth of rice cutgrass (Leersia oryzoides Sw.) and tall fescue (Festuca arundinacea Schreb.) was not enhanced by phosphorus fertilization.

The broad bean crops inoculated with Trichoderma T1R3 strain showed significant differences respect to the control (Fig. 1). The fungus application considerably stimulated broad bean plant growth, and possibly increased phosphorus and nitrogen uptake and the production of auxin and siderophores, ameliorating the adverse effects of As toxicity (Zhang et al. 2018; Khoshmanzar et al. 2019). These results are in accordance with those reported by Caporale et al. (2014), who published the beneficial effects of Trichoderma harzianum strain T22 and Trichoderma atroviride strain P1 on lettuce growth. These authors also reported a reduction of As toxicity when the plants were irrigated with Ascontaminated water ( 5 and $10 \mathrm{mg} \mathrm{L}^{-1}$ ). In this sense, Anawar et al. (2018) revealed that irrigating with Asrich water may change the As-phosphorus balance in the soil solution, causing the mobilization and availability of phosphorus for the plant nutrition. Furthermore, Tripathi et al. (2017) suggested that As is methylated in soils that have been inoculated with Trichoderma, and this could alleviate As stress in chickpea. Besides, as mentioned before, broad bean and chard crops growth might be determined by the synergistic relationships among the Trichoderma T1R3 strain, changes in As availability, and the physiological responses of the crops.

3.3 Influence of llama manure and Trichoderma strain T1R3 on arsenic absorption by Swiss chard and broad bean crops

In this study, the results showed that the application of llama manure and llama manure/ Trichoderma T1R3 combination, significantly reduced As concentration in chard roots and leaves. The Trichoderma strain application, significantly decreases the As concentration in chard root, compared to the controls (Table 3).

In the broad bean crops with llama manure amendments and the addition of llama manure/ Trichoderma T1R3 combination, significantly reduced the As content in bean roots. Also, in bean leaves, the addition of Ilama manure and Trichoderma T1R3 inoculation significantly lowered As concentration, as compared with the control (Table 4). In contrast, Trichoderma strain led to the highest As accumulation in broad bean roots, with concentrations significantly higher in comparison to the other treatments (Table 4).

The lower As absorption in chard and broad bean (roots and leaves), can be attributed to the combined effect of microbial activity, As adsorption to soil particles and organic material, such as manure. Adsorption is the first process that takes place when As are in contact with a soil, affecting processes such as leaching, bioavailability or toxicity (Morillo and Villaverde, 2017). This strategy leads to a reduced availability of As, which in turns improves plant growth (Mehmood et al. 2017; Nawab et al. 2018). In this sense, Mehmood et al. (2017) reported that in the (sandy loam) soil in Narwala, contaminated with As (0, $\left.40,80,120 \mathrm{mg} \mathrm{kg}^{-1}\right)$, the addition of compost (2.5\%) decreases As concentration in maize shoot, significantly improving shoot dry biomass. In addition, Nawab et al. (2018) demonstrated that applying 
$5 \%$ farmyard manure to the soil showed the highest reduction in As bioaccumulation in pea (21 to $37 \%$ ) and chili (18 to 36\%), respect to the control treatments. Also, Trichoderma induced As methylation in soil could be the reason for less As uptake in Trichoderma inoculated plants. This loss of As could be due to volatilization of methylated As, such as in the form of trimethylarsine (TMA) or trimethylarsine oxide (TMAO) (Wang et al. 2015; Tripathi et al. 2017). Lower root uptake of methylated As species has been reported by several studies (Mishra et al. 2016 and 2017).

Furthermore, organic matter decomposition results in a release of simple aliphatic acids, sugar acids, amino acids, phenols, phosphates and carbonate minerals, which act as adsorption sites for As ions. This reduces their mobility in the soil solution, mitigating As toxicity hazards and making the toxicant unavailable for plants (Mehmood et al. 2017; Nawab et al. 2018; Mandal et al. 2019). The presence of phosphorus in the soil $\left(72.8 \mathrm{mg} \mathrm{kg}^{-1}\right)$ and in the llama manure $\left(418 \mathrm{mg} \mathrm{kg}^{-1}\right)$ may have positive effects on plant growth and reduce As uptake. This is possibly due to the fact that in plant cells, phosphorus can compete with As $(\operatorname{As}(\mathrm{V}))$ in different important biochemical processes, where As substitutes for phosphorus (Niazi et al. 2017).

The $\mathrm{pH}$ of the soil plays an important role in the As bioavailability, and its subsequent bioaccumulation in plants (Nawab at al. 2018). In the present study, the alkaline pH of the soil and water (Table 2) could have contributed to As coprecipitation with sulfate or calcium, reducing its availability (Natasha et al. 2020). According to Chaoua et al. (2019), in alkaline pH soils, the concentrations of metal ions drop due to an increased surface oxide charge, or on account of either processes of precipitation of metal hydroxides, or of formation of insoluble organic complexes.

In addition, calcium is generally known to reduce As accumulation in plants by forming stable Caarsenate precipitates (Hassan et al. 2014). In this study, high calcium concentrations in the soil (8.8 meq $\left.\mathrm{L}^{-1}\right)$ and in the irrigation water $\left(4\right.$ meq $\left.\mathrm{L}^{-1}\right)$ could form stable precipitates, such as calcium arsenate, and reduce As uptake by crops. This was observed by Liu et al. (2014), reported that applying $\mathrm{CaO}_{2}$ to the soil significantly reduced As accumulation in celery shoots. Similarly, Shahid et al. (2017) reported that the application of $\mathrm{Ca}(1,5$ and $10 \mathrm{mM})$ significantly reduced As transfer to spinach aerial parts.

In this study, the high levels of As $\left(590.83 \mathrm{mg} \mathrm{kg}^{-1}\right)$ accumulated in broad bean roots (Trichoderma strain treatment) could be attributed to the fact that Trichoderma T1R3 released organic acids, such as gluconic acid, fumaric acid, and citric acid, which decreased soil $\mathrm{pH}$ and caused the dissolution of phosphate and As, among other compounds, thus resulting in a greater bioavailability of the toxicant and of nutrients in the rhizosphere (Stewart et al. 2014; Anawar et al. 2018). In the two crops studied in this work, the roots were the organs with the highest accumulated As, probably attributed to the toxicant was compartmentalized in root vacuoles, gets complexed with sulfhydryl $(-\mathrm{SH})$ groups of peptides, such as $\mathrm{Y}^{-}$ glutamylcysteine, glutathione and phytochelatins (Mishra et al. 2016 and 2017). These phenomena were observed in crops such as rice, tomato, beans, chard and lettuce (Caporale et al. 2013; Pigna et al. 2013; Yañez et al. 2018 and 2019). The results presented in this work are consistent with previous studies by Kumwimba et al. (2013), these authors reported values of $534.06 \mathrm{mg} \mathrm{kg}^{-1}$ As in roots of hydroponic 
lettuce crops, showed that the average As concentration in roots was 19-26 times higher than in shoots. Also, studies conducted by Babu et al. (2014), who inoculated a metal-polluted mining ground with Trichoderma virens chlamydospores, and grew corn plants to evaluate the mobility of toxicants, found that the fungus significantly increased As accumulation in corn roots (31\%), compared with plants grown in soils without inoculation.

In our study, broad bean crops did not develop pods with seeds, so As could not be quantified. The salinity of llama manure $\left(12.76 \mathrm{dS} \mathrm{m}^{-1}\right)$, the soil $\left(1.98 \mathrm{dS} \mathrm{m}^{-1}\right)$, and the irrigation water $\left(2.58 \mathrm{dS} \mathrm{m}^{-1}\right)$ could have negatively affected crop development. Saline medium has several adverse effects on plant growth, as a result of a low osmotic potential of the soil solution (osmotic stress), specific ion effects, nutritional imbalance, or a combination of these factors (Rafiq et al. 2017; Parvez et al. 2020). Moreover, chlorosis symptoms were observed in the leaves, which were later affected by foliar necrosis.

3.4 Arsenic translocation factors in Swiss chard and broad bean crops applied with llama manure and Trichoderma T1R3

The ability of plants to mobilize As from roots to leaves was calculated as a translocation factor (TF). Due to high accumulation of As in plant roots, As translocation from root to leaves was low (TF $<1)$ in all As treatments (Table 5). According to Sharma et al. (2020), a TF $<1$ indicates poor As translocation from roots to the aerial parts. It could be observed that $\mathrm{FT}=0.01$ value for broad bean crop treated with Trichoderma strain showed a considerably lower translocation of the toxicant from the roots to the leaves, respect to the control treatment. In this sense, Khan et al. (2009) reported that a TF value $\leq 0.1$ would indicate that the plant reduces the amount of accumulated toxicant by expelling from the plant tissue, as a detoxification mechanism. The same phenomenon was reported by Caporale et al. (2014), who demonstrated that lettuce plants inoculated with two Trichoderma strains, and irrigated with Ascontaminated water ( 5 or $10 \mathrm{mg} \mathrm{L}^{-1}$ ), showed a significantly lower concentration of As in leaves, respect to the non-treated control. Also, Tripathi et al. (2017) published that As concentration decreased in chickpea plants (root, stem, seeds) inoculated with Trichoderma sp. Thus, a low As concentration in the leaves could be due to limited translocation at a systemic level (Smith et al. 2009). In addition, the higher retention of As in roots could be caused by a process saturation, where plants exceed their capacity of translocating the toxicant to aerial parts (Gusman et al. 2013.

The TF of 0.33 determined for the broad bean crop treated with the llama manure/ Trichoderma T1R3 combination showed a higher As translocation from root to leaves, respect to the control (TF of 0.15). Considering that the As is translocated from the root to the leaves through phosphate channels (Niazi et al. 2016), this may be attributable to better solubilization of phosphorus caused by the T1R3 strain and to the bioavailable phosphorous present in Ilama manure. Yao et al. (2009), also observed that the application of $4 \%$ chicken manure and $4 \%$ pig manure to water spinach enhanced As translocation. Also, Niazi et al. (2017) obtained higher TF values in B. napus, which suggests that this plant species is efficient in transferring As from roots to shoots in presence of phosphate. 
In our study, broad bean plants showed a greater capacity of translocate As than chard plants, except in the Trichoderma T1R3 treatment. In the llama manure treatments and in those with the llama manure/ Trichoderma T1R3 combination, the bean crops had As TF values which were two-fold and threefold higher than those of chard crops, respectively.

3.5 Potential health risks associated with the consumption of Swiss chard leaves from crops exposed to arsenic, and supplemented with llama manure and Trichoderma T1R3

The food chain is an important pathway for human exposure to As. The risk to human health by the intake of As through consuming chard crops was assessed using the hazard quotient (HQ). As shown in Table 6, the applications with Ilama manure and the llama manure/ Trichoderma T1R3 combination to chard crops grown in As-contaminated soil and irrigated with As-contaminated water brought HQ indices below 1, compared to the control treatment. According to USEPA (2000) guidelines, potential adverse impact on human health would occur when $H Q \geq 1$, whereas $H Q<1$ values mean that the exposed population is unlikely to experience adverse health effects. Recently, Mandal et al. (2019) showed that adding farmyard manure to a soil contaminated by $A s\left(10,20,30\right.$, and $\left.40 \mathrm{mgAs} \mathrm{kg}{ }^{-1}\right)$ reduces hazard quotient values for intake of As through the consumption of wheat grown in contaminated soil.

The carcinogenic risk (CR) posed by consuming As-contaminated chard leaves is shown in Table 6. Applications of Ilama manure and the llama manure/ Trichoderma T1R3 combination to chard crops significantly decreased the $\mathrm{CR}$, compared to the control. However, CR values obtained for As were not within the acceptable range, and exceeded the threshold value $\left(1 \times 10^{-4}\right)$, which suggests that consuming leafy vegetables involves a considerably high risk of developing cancer (Muñoz et al. 2017). This CR values were consistent with those reported by Ma et al. (2017), who evaluated the consumption of leafy

vegetables from thirteen different crops, reporting CR values between $1.28 \times 10^{-4}$ and $4.57 \times 10^{-4}$. Also, risk assessment studies conducted by Nawab et al. (2018) showed that applying 1, 2 and $5 \%$ farm manure and peat to agricultural soils contaminated with $\mathrm{Ni}, \mathrm{Cr}, \mathrm{As}, \mathrm{Zn}, \mathrm{Cd}$ and $\mathrm{Pb}$ decreased their daily intake of these metals, as well as the cancer risks associated with rice consumption. The major source of human exposure to As is through consumption of As-accumulating crops and vegetables. However, the inhalation of soil particles, drinking water and dermal contact are important pathways for human exposure to As (Li et al. 2017).

\section{Conclusion}

In the present study evaluated the effect of llama manure amendment and Trichoderma strain T1R3 inoculation on As uptake and toxicity in chard an broad bean crops, together with human health risks associated with the consumption from these crops. In both crops, the combined addition of llama manure and Trichoderma T1R3 was the treatment that most efficiently reduced As accumulation in chard leaves and in the roots of both crops, showing a great potential as an As complexing agent, and a capacity to reduce plant As uptake and its availability in the soil. The TFs of broad beans were also higher than those of chard; however, specifically in broad bean, treatments with Trichoderma T1R3 strain

Page 12/23 
led to a considerably lower translocation of the toxicant from the roots to the leaves. In addition, the llama manure/ Trichoderma T1R3 combination was more effective in reducing Hazard quotients (HQ) and Carcinogenic risk (CR) represented by consuming chard leaves. However, CR values obtained for As were higher than those acceptable, which means that there is a considerable carcinogenic risk in consuming leafy vegetables.

This work indicates that it is possible combine bio-fertilization and mitigation of As toxicity in important food crops by using selected Trichoderma strains. Further research is needed in relation to the role llama manure and Trichoderma T1R3 play in As immobilization/mobilization and its uptake by different plant species that are grown in a range of As-contaminated soils. Therefore, if becomes of primary importance to perform detailed studies and development of strategies that minimize the water-soil-plant transfer of arsenic or restrict As contamination of edible plant parts, preventing root-to-shoot translocation. These strategies would be sufficient to become another route for increasing food safety.

\section{Declarations}

\section{Declarations}

Conflict of interest On behalf of all authors, the corresponding author states that there is no confict of interest.

\section{Authors Contributions}

LMY: designed the study, and analyzed the data, discussion of the results, and writing of the manuscript. JAA: designed the study, conducted the experiments and data compilation, discussion of the results.

NMEAC: analyzed the data, acquisition and administration of funds

GBM: methodology planning, acquisition and administration of funds.

All authors reviewed and approved the final manuscript.

\section{Acknowledgments}

This work was supported by Consejo Nacional de Investigaciones Científicas y Técnicas (CONICET) and the PIO Project CONICET-UNJU No $14020140100136 C O$. The authors would also like to thank Dra. Maria Paula Filippone and the Investigación en Química Aplicada (INQA) group, from the Faculty of Agricultural Sciences, University of Jujuy (Argentina), for their valuable contributions to this work.

\section{References}

Acosta-Motos JR, Ortuño MF, Bernal-Vicente A, Diaz-Vivancos P, Sanchez-Blanco MJ, Hernandez JA (2017) Plant Responses to Salt Stress: Adaptive Mechanisms. Agronomy 7-18 
Anawar HM, Rengel Z, Damon P, Tibbett M (2018) Arsenic-phosphorus interactions in the soil-plantmicrobe system: Dynamics of uptake, suppression and toxicity to plants. Environ Pollut 233:1003-1012

Arco-Lázaro E, Agudo I, Clemente R, Bernal MP (2016) Arsenic (V) adsorption desorption in agricultural and mine soils: effects of organic matter addition and phosphate competition. Environ Pollut 216:71-79

Babu AG, Shim J, Bang KS, Shea PJ, Oh BT (2014) Trichoderma virens PDR-28: a heavy metal-tolerant and plant growth-promoting fungus for remediation and bioenergy crop production on mine tailing soil. $J$ Environ Manag 132:129-134

Bray RH, Kurtz LT (1945) Determination of total, organic and available forms of phosphorus in soils. Soil Sci 59:39-46

Bremner JM, Mulvaney CS (1982) Nitrogen-Total. In: Methods of soil analysis. Part 2. Chemical and microbiological properties, Page, A.L., Miller, R.H. and Keeney, D.R. Eds., American Society of Agronomy, Soil Science Society of America, Madison, Wisconsin, 595-624

Caporale AG, Pigna M, Sommella A, Dynes JJ, Cozzolino V, Violante A (2013) Influence of compost on the mobility of arsenic in soil and its uptake by bean plants (Phaseolus vulgaris L.) irrigated with arsenitecontaminated water. J Environ Manag 128:837-843

Caporale AG, Sommella A, Lorito M, Lombardi N, Azam SM, Pigna M, Ruocco, M (2014) Trichoderma spp. alleviate phytotoxicity in lettuce plants (Lactuca sativa L.) irrigated with arsenic-contaminated water. J Plant Physiol 171:1378-1384

Chan M, Selvam A, Wong JWC (2016) Reducing nitrogen loss and salinity during 'struvite' food waste composting by zeolite amendment. Bioresour Technol 200:838-844

Chaoua S, Boussaa S, Gharmali AE, Boumezzough A (2019) Impact of irrigation with wastewater on accumulation of heavy metals in soil and crops in the region of Marrakech in Morocco. J Saudi Soc Agr Sci 18:429-436

Costa SM de, Montenegro MA, Arregui T, Pinto MIS de, Nazareno MA, Mishima BL de (2003) Characterization of fresh Beta vulgaris from Santiago del Estero (Argentina). Nutrient and caroteniod content of stem and leaves. Ciênc Tecnol Aliment 23:33-37

Eaton AD, Clesceri LS, Rice EW, Greenberg AE (2005) Standard methods for the examination of water and wastewater, $21^{\text {st }}$ edn. APHA, Washington DC

Farooq MA, Islam F, Ali B, Najeeb U, Mao BZ, Gill RA, Yan GJ, Siddique KHM, Zhou WJ (2016) Arsenic toxicity in plants: cellular and molecular mechanisms of its transport and metabolism. Environ Exp Bot 132:42-52 
Gadepalle VP, Ouki SK, Van Herwijnen R, Hutchings T (2008) Effects of amended compost on mobility and uptake of arsenic by rye grass in contaminated soil. Chemosphere 72:1056-1061

Govarthanan M, Mythili R, Selvankumar T, Kamala-Kannan S, Kim H (2018) Myco-phytoremediation of arsenic- and lead-contaminated soils by Helianthus annuus and wood rot fungi, Trichoderma sp. isolated from decayed wood. Ecotox Environ Safe 151:279-284

Govarthanan M, Mythili R, Kamala-Kannan S, Selvankumar T, Srinivasan P, Kim H (2019a) In-vitro biomineralization of arsenic and lead from aqueous solution and soil by wood rot fungus, Trichoderma sp. Ecotox Environ Safe 174:699-705

Govarthanan M, Selvankumar T, Mythili R, Srinivasan P, Ameen F, AlYahya SA, Kamala-Kannan S (2019b) Biogreen remediation of chromium-contaminated soil using Pseudomonas sp. (RPT) and neem (Azadirachta indica) oil cake. Int J Environ Sci Technol 16:4595-4600

Gusman GS, Olivera JA, Farnese FS, Cambria J (2013) Arsenate and arsenite: the toxic effect on photosynthesis and growth of lettuce plants. Act Physiol Plant 35:1201-1209

Hassan A, Abdel-Mohsen A, Elhadidy H (2014) Adsorption of arsenic by activated carbon, calcium alginate and their composite beads. Int $\mathrm{J}$ Biol Macromol 68:125-130

Joardar J, Kawai S (2014) Phosphate rich soil additive baked pig manure effectively reduces arsenic concentration in Japanese mustard spinach (Brassica rapa var. perviridis) grown with arsenic contaminated irrigation water. Am J Expermental Agric 4:142-152

Khan S, Farooq R, Shahbaz S, Khan AM, Sadique M (2009) Health risk assessment of heavy metals for population via consumption of vegetables. World App Sci J 6:1602-1606

Khoshmanzar E, Aliasgharzad N, Neyshabouri MR, Khoshru B, Arzanlou M, Lajayer BA (2019) Effects of Trichoderma isolates on tomato growth and inducing its tolerance to water-deficit stress. Int J Environ Sci Technol 17:869-878

Klaber NS, Barker AV (2014) Accumulation of phosphorus and arsenic in two perennial grasses for soil remediation. Commun Soil Sci Plan 45:810-818

Kumwimba MN, Xibai Z, Lingyu B (2013) Uptake kinetics of arsenic by lettuce cultivars under hydroponics. Afr J Environ Sci Technol 73:21-328

Li L, Hang Z, Yang W-T, Gu J-F, Liao B-H (2017) Arsenic in vegetables poses a health risk in the vicinity of a mining area in the southern Hunan Province, China. Hum Ecol Risk Assess Int J 23:1315-29 
Li L, Zeng X, Chen JY, Tian J, Huang J, Su S (2021) Genome Sequence of the Fungus Trichoderma asperellum SM-12F1 revealing candidate Functions of Growth Promotion, Biocontrol, and Bioremediation. PhytoFrontiers, (ja)

Liu L, Chen H, Cai P, Liang W, Huang Q (2009) Immobilization and phytotoxicity of Cd in contaminated soil amended with chicken manure compost. J Hazard Mater 163:563-567

Liu R, Yang C, Li S, Sun P, Shen S, Li Z (2014) Arsenic mobility in the arsenic-contaminated Yangzonghai Lake in China. Ecotox Environ Safe 107:321-327

Luo ZB, He J, Polle A, Rennenberg H (2016) Heavy metal accumulation and signal transduction in herbaceous and woody plants: Paving the way for enhancing phytoremediation efficiency. Biotechnol Adv $34: 1131-1148$

Ma L, Yang Z, Kong Q, Wang L (2017) Extraction and determination of arsenic species in leafy vegetables: method development and application. Food Chem 217:524-530

Mandal J, Golui D, Datta SP (2019) Assessing equilibria of organo-arsenic complexes and predicting uptake of arsenic by wheat grain from organic matter amended soils. Chemosphere 234:419-426

Mehmood T, Bibi I, Shahid M, Niazi NK, Murtaza B, Wang H, Ok YS, Sarkar B, Javed MT, Murtaza G (2017) Effect of compost addition on arsenic uptake, morphological and physiological attributes of maize plants grown in contrasting soils. J Geochem Explor 178:83-91

Mirza N, Mubarak H, Chai LY, Yang ZH, Mahmood Q, Yong W, Tang CJ,

Fahad S, Nasim W (2016) Constitutional tolerance and chlorophyll fluorescence of

Boehmeria nivea $\mathrm{L}$ in response to the antimony (Sb) and arsenic (As) co-contamination. Toxicol Environ Chem 99:265-272

Mishra S, Alfeld M, Sobotka R, Andresen E, Falkenberg G, Kupper H (2016) Analysis of sublethal arsenic toxicity to Ceratophyllum demersum: subcellular distribution of arsenic and inhibition of chlorophyll biosynthesis. J Exp Bot 67:4639-4646

Mishra S, Mattusch J, Wennrich R (2017) Accumulation and transformation of inorganic and organic arsenic in rice and role of thiol complexation to restrict their translocation to shoot. Sci Rep 7:40522

Morillo E, Villaverde J (2017) Advanced technologies for the remediation of pesticide contaminated soils. Sci Total Environ J 586, 576-597.

Muñoz O, Zamorano P, Garcia O, Bastías JM (2017) Arsenic, cadmium, mercury, sodium, and potassium concentrations in common foods and estimated daily intake of the population in Valdivia (Chile) using a total diet study. Food Chem Toxicol 109:1125-1134 
Natasha M, Shahid Khalid S, Murtaza B, Anwar H, Shah AH, Sardar A, Shabbir Z, Niazi NK (2020) A critical analysis of wastewater use in agriculture and associated health risks in Pakistan. Environ Geochem HIth https://doi.org/10.1007/s10653-020-00702-3

National Law (N²4,585) (1995) Protección ambiental para la actividad minera del codigo de minería. Available on: https://www.entrerios.gov.ar/ambiente/ userfiles/files/archivos/Normativas/Nacionales/Ley\%2024585_Act_Min_EIA.pdf

National Law (No 24,051) (1993) Residuos peligrosos. Available on: http://servicios.infoleg.gob.ar/infolegInternet/anexos/10000-14999/12830/texact.htm

Nawab J, Khan S, Aamir M, Shamshad I, Qamar Z, Din I, Huang Q (2016) Organic amendments impact the availability of TMs(loid)s in mine-impacted soil and their phytoremediation by Penisitum americanum and Sorghum bicolor. Environ Sci Pollut Res 23:2381-2390

Nawab J, Ghani J, Khan S, Xiaoping W (2018) Minimizing the risk to human health due to the ingestion of arsenic and toxic metals in vegetables by the application of biochar, farmyard manure and peat moss. $J$ Environ Manag 214:172-183

Nelson DW, Sommers LE (1982) Total carbon, organic carbon and organic matter. In: Page AL (ed) Methods of soil analysis, Part 2 (2nd). Madison, Wl: American Society of Agronomy 9:539-579

Niazi NK, Bashir S, Bibi I, Murtaza B, Shahid M, Javed MT, Shakoor MB, Saqib ZA, Nawaz MF, Aslam Z, Wang H, Murtaza G (2016) Phytoremediation of arsenic-contaminated soils using arsenic hyperaccumulating ferns. In: A A Ansari, S S Gill, R Gill, G R Lanza. L Newman eds. Phytoremediation: Management of Environmental Contaminants Switzerland: Springer International p. 521-545

Niazi NK, Bibi I, Fatimah A, Shahid M, Javed MT, Wang H, Ok YS, Bashir S, Murtaza B, Saqib ZA (2017) Phosphate-assisted phytoremediation of arsenic by Brassica napus and Brassica juncea: Morphological and physiological response. Int J Phytoremediat 19:670-678

Parvez S, Abbas G, Shahid M, Amjad M, Hussain M, Asad SA, Imran M, Naeem MA (2020) Effect of salinity on physiological, biochemical and photostabilizing attributes of two genotypes of quinoa (Chenopodium quinoa Willd.) exposed to arsenic stress. Ecotox Environ Safe 187:109814

Pigna M, Caporale AG, Cozzolino V, Lopez CF, Mora ML, Sommella A, Violante A (2013) Influence of phosphorus on the arsenic uptake by tomato (Solanum lycopersicum L.) irrigated with arsenic solutions at four different concentrations. J Soil Sci Plant Nutr 12:775-784

PIP (Plan de Implementacion Provincial) (2016) Ministerio de Desarrollo Económico y Producción. Available on: https://www.magyp.gob.ar/sitio/areas/pisear/biblioteca/PIP\%20Jujuy.pdf

Poveda J (2021) Glucosinolates profile of Arabidopsis thaliana modified root colonization of Trichoderma species. Biol Control 155:104522 
Rafiq M, Shahid M, Abbas G, Shamshad S, Khalid S, Niazi NK, Dumat C (2017)

Comparative effect of calcium and EDTA on arsenic uptake and physiological attributes of Pisum sativum. Int J Phytoremediat 19:662-669

Richards LA (1982) Diagnóstico y rehabilitación de los suelos salinos y sódicos. Limusa

(ed), México, p 172

Shahid M, Rafiq M, Niazi NK, Dumat C, Shamshad S, Khalid S, Bibi I (2017) Arsenic accumulation and physiological attributes of spinach in the presence of amendments: an implication to reduce health risk. Environ Sci Pollut Res 24:16097-16106

Sharma S, Kumar R, Sahoo PK, Mittal S (2020) Geochemical relationship and translocation mechanism of arsenic in rice plants: A case study from health prone south west Punjab (p. 100333). India: Groundwater for Sustainable Development

Shrivastav P, Prasad M, Singh TB, Yadav A, Goyal D, Ali A, Dantu PK (2020) Role of nutrients in plant growth and development. In: Naeem M, Ansari AA, Gill SS (eds) Contaminants in agriculture. Springer, Cham, pp 43-59

Smith E, Juhasz AL, Weber J (2009) Arsenic uptake and speciation in vegetables grown under greenhouse conditions. Environ Geochem Hlth 31:125-132

Stewart A, Hill R (2014) Applications of Trichoderma in Plant Growth Promotion. In: Biotechnology and Biology of Trichoderma 31:415-425

Su SM, Zeng XB, Bai LY, Paul N, Wang YY, Wu CX (2017) Inoculating chlamydospores of Trichoderma asperellum SM-12F1 changes arsenic availability and enzyme activity in soils and improves water spinach growth. Chemosphere 175:497-504.

Tripathi P, Singh PC, Mishra A, Chaudhry V, Mishra S, Tripathi RD, Nautiyal CS (2013) Trichoderma inoculation ameliorates arsenic induced phytotoxic changes in gene expression and stem anatomy of chickpea (Cicer arietinum). Ecotox Environ Safe 89:8 14

Tripathi P, Singh PC, Mishra A, Tripathi RD, Nautiyal CS (2015) Trichoderma inoculation augments grain amino acids and mineral nutrients by modulating arsenic speciation and accumulation in chickpea (Cicer arietinum L.). Ecotox Environ Safe 117:72-80

Tripathi P, Singh PC, Mishra A, Srivastava S, Chauhan R, Awasthi S, Mishra S, Dwivedi S, Tripathi P, Kalra A, Tripathi RD, Nautiyal CS (2017) Arsenic tolerant Trichoderma sp. reduces arsenic induced stress in chickpea (Cicer arietinum). Environ Pollut 223:137-145

Urunmatsoma SOP, Ikhuoria EU, Okieimen FE (2010) Chemical fractionation and heavy metal accumulation in maize (Zea mays) grown on chromated copper arsenate (CCA) contaminated soil 
amended with cow dung manure. Int J Biotechnol Mol Biol Res 1:65-73

USEPA (US Environmental Protection Agency) (1996) Method 3050 B: Acid digestion of sediments, sludges and soils. Revision 2. Washington, DC

USEPA (US Environmental Protection Agency) (2000) Risk Based Concentration Table. (Philadelphia, PA; Washington, DC). Available on: https://www.epa.gov/iris

USEPA (US Environmental Protection Agency) (2015) Human health risk assessment. Regional Screening Level (RSL) Summary Table. Available online at: 〈http:// www.epa.gov/ reg3hwmd/risk/human/rbconcentration_table/Generic_Tables/ docs/master_sl_table_run_JAN2015.pdf $\rangle$

Wang XR, Su SM, Zeng XB, Bai LY, Li LF, Ran D, Wang Y, Wu CX (2015) Inoculation with chlamydospores of Trichoderma asperellum SM-12F1 accelerated arsenic volatilization and influenced arsenic availability in soils. J Integr Agric 14:389-397

Yañez LM, Alfaro JA, Bovi Mitre G (2017) Selección de cepas de Trichoderma spp. tolerantes al arsénico y con capacidad de remoción en medio líquido. Agraria, Revista Científica. Facultad de Ciencias Agrarias Universidad Nacional de Jujuy. Vol. X, 17: 21-28. Available in: http://www.fca.unju.edu.ar/media/revista_agraria/revista-_agraria_2017_04-06.pdf

Yañez LM, Alfaro JA, Bovi G (2018) Absorption of arsenic from soil and water by two chards (Beta vulgaris L.) varieties: a potential risk to human health. J Environ Manag 218:23-30

Yañez LM, Alfaro JA, Avila Carreras NME, Bovi Mitre G (2019) Arsenic accumulation in lettuce (Lactuca sativa L.) and broad bean (Vicia faba L.) crops and its potential risk for human consumption. Heliyon 5 , e01152. doi: 10.1016/j.heliyon.2019. e01152

Yao LX, Li GL, Dang Z, He ZH, Zhou CM, Yang BM (2009) Arsenic uptake by two vegetables grown in two soils amended with As-bearing animal manures. J Hazard Mater 164:904-910

Zhang H, Zeng X, Bai L, Shan H, Wang Y, Wu C, Duan R, Su S (2018) Reduced arsenic availability and plant uptake and improved soil microbial diversity through combined addition of ferrihydrite and Trichoderma asperellum SM-12F1. Environ Sci Pollut Res 25:24125-24134

\section{Tables}

Table 1: Parameters and values used in risk assessment equations 


\begin{tabular}{|c|c|c|}
\hline Abbreviation & Parameter & Value \\
\hline EF (days/year) & Exposure frequency & 48 \\
\hline ED (years) & Exposure duration & 70 \\
\hline FIR (g/day) & Food ingestion rate & 200 \\
\hline $\mathrm{C}(\mathrm{mg} / \mathrm{kg})$ & As concentration in Swiss chard & Table 2 \\
\hline $\mathrm{RfD}(\mathrm{mg} / \mathrm{kg}$ day) & Arsenic reference dose & 0.0003 \\
\hline BW (kg) & Body weight & 70 \\
\hline AT (days) & Average time for non-carcinogens & 365 \\
\hline CSF (kg day/mg) & Arsenic oral cancer slope factor & 1.5 \\
\hline
\end{tabular}

Source: USEPA (2015); Shahid et al. (2017)

Table 2: Physicochemical properties of the soil, Ilama manure and irrigation water sampled from Pastos Chicos. 


\begin{tabular}{|c|c|c|c|c|}
\hline Soil & Value & Manure & $\begin{array}{l}\text { Value } \\
\text { Value }\end{array}$ & Water \\
\hline pH (1:2.5, soil:water) & 8.3 & $\begin{array}{l}\mathrm{pH}(1: 2.5 \\
\text { soil:water) }\end{array}$ & $\begin{array}{l}7.6 \\
8.25\end{array}$ & $\mathrm{pH}$ \\
\hline $\mathrm{pH}$ of extract & 8.12 & $\mathrm{pH}$ of extract & $\begin{array}{l}7.36 \\
2.6\end{array}$ & $\mathrm{EC}\left(\mathrm{dS} \mathrm{m^{-1 }}\right)$ \\
\hline Organic carbon (\%) & 5.12 & $\begin{array}{l}\text { Organic } \\
\text { carbon (\%) }\end{array}$ & 234.0 & $\mathrm{Ca}\left(\mathrm{meq} \mathrm{L}^{-1}\right)$ \\
\hline Total nitrogen (\%) & 0.25 & $\begin{array}{l}\text { Total nitrogen } \\
(\%)\end{array}$ & ${ }^{1.6} 2.6$ & $\mathrm{Mg}\left(\right.$ meq L $\left.^{-1}\right)$ \\
\hline Ratio C/N & 9.14 & Ratio $\mathrm{C} / \mathrm{N}$ & $\begin{array}{l}14.0 \\
18.0\end{array}$ & $\mathrm{Na}\left(\mathrm{meq} \mathrm{L}^{-1}\right)$ \\
\hline$E C\left(d S m^{-1}\right)$ & 1.98 & $\mathrm{EC}\left(\mathrm{dS} \mathrm{m^{-1 } )}\right.$ & $\begin{array}{r}12.76 \\
1.4\end{array}$ & $\mathrm{~K}\left(\right.$ meq $\left.\mathrm{L}^{-1}\right)$ \\
\hline Extractable $\mathrm{P}\left(\mathrm{mg} \mathrm{kg}^{-1}\right)$ & 72.8 & $\begin{array}{l}\text { Extractable P } \\
\left(\mathrm{mg} \mathrm{kg}^{-1}\right)\end{array}$ & $\begin{array}{r}418 \\
1.02\end{array}$ & Carbonate (meq L-1) \\
\hline $\mathrm{Ca}\left(\mathrm{meq} \mathrm{L}^{-1}\right)$ & 8.8 & $\begin{array}{l}\text { Extractable } \\
\mathrm{K}\left(\mathrm{mg} \mathrm{kg}^{-1}\right)\end{array}$ & $\begin{array}{r}9048 \\
4.08\end{array}$ & Bicarbonate (meq L-1) \\
\hline $\operatorname{Mg}\left(\right.$ meq $\left.L^{-1}\right)$ & 3.4 & $\begin{array}{l}\mathrm{Na}\left(\mathrm{cmol}_{\mathrm{C}} \mathrm{kg}^{-}\right. \\
\left.{ }^{1}\right)\end{array}$ & $\begin{array}{l}15.10 \\
\quad 6.28\end{array}$ & Chlorides (meq L-1) \\
\hline Clay (\%) & 15.2 & $\mathrm{~K}\left(\mathrm{cmol}_{\mathrm{C}} \mathrm{kg}^{-1}\right)$ & $\begin{array}{l}23.20 \\
14.61\end{array}$ & Sulfates (meq L-1) \\
\hline Silt (\%) & 7.5 & $\begin{array}{l}\text { Total As (mg } \\
\mathrm{kg}^{-1} \text { ) }\end{array}$ & $\begin{array}{l}13.3 \\
9.92\end{array}$ & SAR \\
\hline Sand (\%) & 77.3 & & C4 S3 & erside classification \\
\hline Total As $\left(\mathrm{mg} \mathrm{kg}^{-1}\right)$ & 49 & & \multicolumn{2}{|c|}{ Total As $\left(\mathrm{mg} \mathrm{L}^{-1}\right)$} \\
\hline
\end{tabular}

EC: electrical conductivity; P: phosphorus; Ca: calcium; Mg: magnesium; C: carbon; N: nitrogen; Na: sodium; K: potassium; SAR: sodium absorption ratio

Table 3: Arsenic concentration (mgAs $\mathrm{kg}^{-1}$ ) in Swiss chard crops 


\begin{tabular}{|c|c|c|c|c|c|}
\hline \multirow[t]{2}{*}{ Treatments } & \multicolumn{2}{|c|}{ Roots } & \multicolumn{3}{|c|}{ Leaves } \\
\hline & \multicolumn{2}{|c|}{$\%$ Reduction } & dry weight & \multicolumn{2}{|c|}{ \% Reduction } \\
\hline Control & $186.40 \pm 5.12^{a}$ & ........ & 12.72 & $0.88^{a}$ & .......... \\
\hline Llama manure & $125.9 \pm 3.55^{b}$ & 32.46 & & $5 \pm 0.60^{b}$ & 35.2 \\
\hline Trich. T1R3 & $171.00 \pm 2.97^{c}$ & 8.26 & 11. & $\pm 0.37^{a}$ & 6.6 \\
\hline Manure/ Trich.T1R3 & $67.06 \pm 3.95^{d}$ & 64.02 & & $\pm 0.33^{b}$ & 44.5 \\
\hline
\end{tabular}

Data are expressed as mean values $\pm \operatorname{SD}(n=3)$. The different letters within a column indicate a significant difference at $p \leq 0.05$ according to Duncan's multiple range tests. The $\%$ reduction was determined considering the As concentration of the control treatment as $100 \%$ As content.

Table 4: Arsenic concentration (mgAs kg ${ }^{-1}$ dry weight) in broad bean crops

\begin{tabular}{|lcccc|}
\hline Treatments & Roots & \% Reduction & Leaves & \% Reduction \\
Control & $160.62 \pm 11.27^{\mathrm{a}}$ & $\ldots \ldots \ldots$ & $24.73 \pm 1.63^{\mathrm{a}}$ & $\ldots \ldots \ldots . .$. \\
Llama manure & $100.81 \pm 7.69^{\mathrm{b}}$ & 37.24 & $11.35 \pm 1.22^{\mathrm{b}}$ & 54.10 \\
Trich. T1R3 & $590.83 \pm 14.14^{\mathrm{c}}$ & $\ldots \ldots \ldots$ & $8.06 \pm 0.25^{\mathrm{c}}$ & 67.42 \\
Manure/ Trich.T1R3 & $68.33 \pm 5.83^{\mathrm{d}}$ & 57.46 & $22.42 \pm 1.05^{\mathrm{a}}$ & 9.32 \\
\hline
\end{tabular}

Data are expressed as mean values $\pm \mathrm{SD}(n=3)$. The different letters within a column indicate a significant difference at $p \leq 0.05$ according to Duncan's multiple range tests. The \% reduction was determined considering the As concentration of the control treatment as $100 \%$ As content.

Table 5: Arsenic translocation in crops

\begin{tabular}{|lcc|}
\hline Treatments & \multicolumn{2}{c|}{ Translocation factor } \\
& Chard & Broad beans \\
Control & 0.07 & 0.15 \\
Llama manure & 0.07 & 0.11 \\
Trich. T1R3 & 0.07 & 0.01 \\
Llama manure/ Trich. T1R3 & 0.11 & 0.33 \\
\hline
\end{tabular}

Table 6: Hazard quotients (HQ) and carcinogenic risk (CR) of arsenic exposure based on chard leave consumption 


\begin{tabular}{|lcc|}
\hline Treatments & HQ & CR \\
\hline Control & $1.50 \pm 0.10^{\mathrm{a}}$ & $6.7 \times 10^{-4} \pm 4.4 \times 10^{-5} \mathrm{a}$ \\
Llama manure & $0.97 \pm 0.07^{\mathrm{b}}$ & $4.4 \times 10^{-4} \pm 3.3 \times 10^{-5} \mathrm{~b}$ \\
Trich. T1R3 & $1.40 \pm 0.04^{\mathrm{a}}$ & $6.3 \times 10^{-4} \pm 1.6 \times 10^{-5} \mathrm{a}$ \\
Llama manure/ Trich. T1R3 & $0.83 \pm 0.04^{\mathrm{b}}$ & $3.8 \times 10^{-4} \pm 2.0 \times 10^{-5} \mathrm{~b}$ \\
\hline
\end{tabular}

Data are expressed as mean values \pm SD $(n=3)$. The different letters within a column indicate a significant difference at $p \leq 0.05$ according to Duncan's multiple range tests.

\section{Figures}

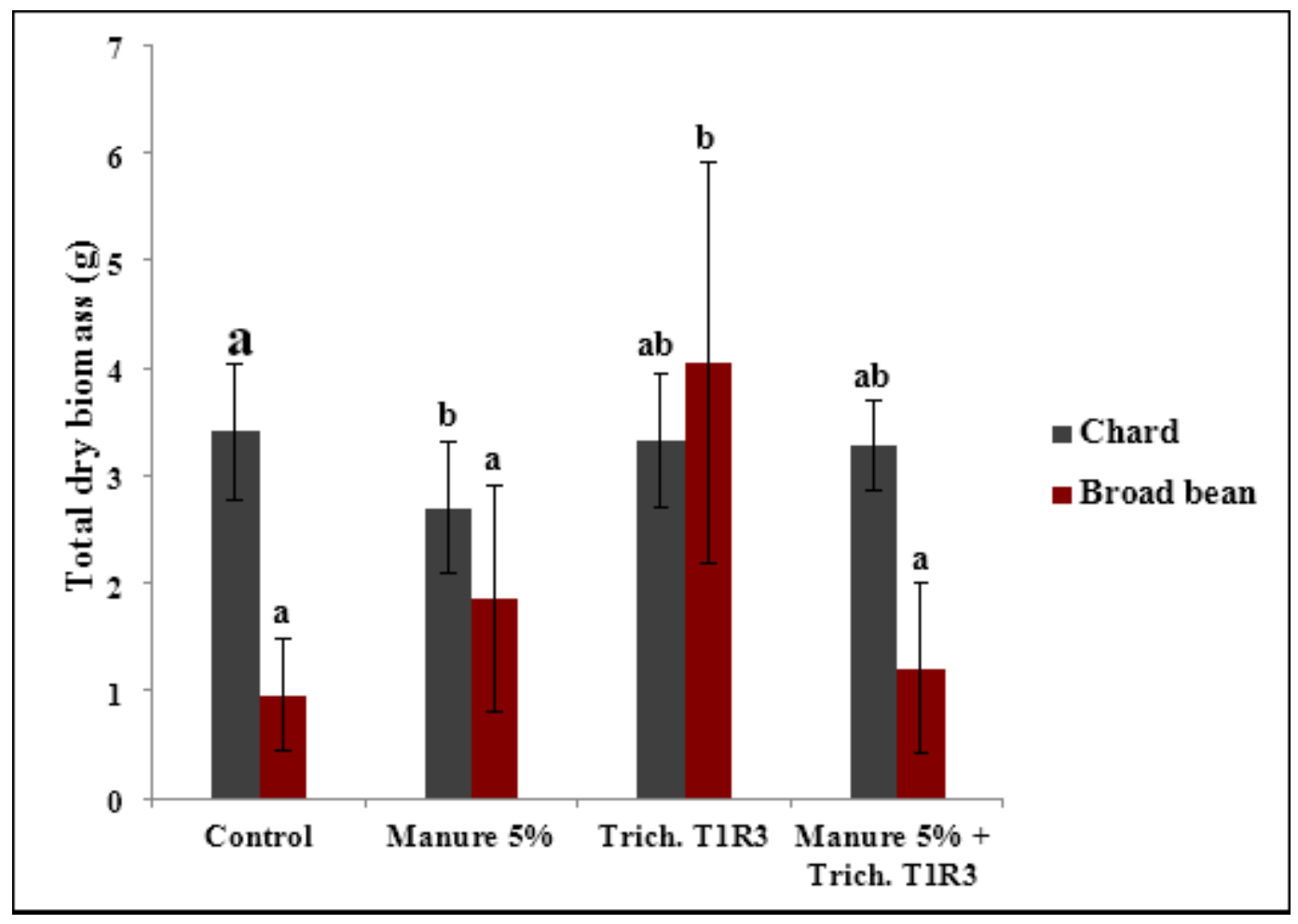

Figure 1

Growth of Swiss chard and broad bean crops exposed to arsenic, llama manure and Trichoderma strain T1R3. Data are expressed as mean values \pm SD $(n=15)$. Bars with different letters significantly differ at the level of $p \leq 0.05$ according to Duncan's multiple range tests. Statistical comparisons among crop treatments, not among different crops. 